Einar Eythórsson

Finnmark Research Centre

Alta

Norway

\title{
A Decade of ITQ-management in Icelandic Fisheries - Consolidation without Consensus
}

A paper to be presented at the eighth IASCP Conference; Constituting the Commons: Crafting Sustainable Commons in the New Millenium.

Bloomington Indiana USA May 31 - June 4, 2000 


\section{Introduction}

As a small island nation in the North-Atlantic, Iceland is heavily dependent upon the fish resources. Fish products are the most important export commodity and fluctuations in catches or seafood market prices tend to generate immediate impacts upon the living standard of most Icelanders.

Good fishing grounds are found in practically all Icelandic waters although the richest demersal grounds are probably to the north-west of the country and on the spawning grounds for cod off the south-west. Consequently, harvesting and fish processing is operated almost all around the coast. The eastern coast is most favourably located for the pelagic (capelin and herring) fisheries. The richest shrimp fisheries are to the north-west, and the lobster fisheries take place off the south coast. Since a major part of the fishing fleet is highly mobile, the comparative advantages of fishing communities located close to the fishing grounds have diminished.

The most important of the Icelandic fisheries is the demersal or groundfish fishery. In recent years this fishery has usually generated over $80 \%$ of the total wetfish value (Runólfsson 1997). The demersal catches (cod, haddock, saith, redfish and Greenland halibut) from Icelandic waters have fluctuated between approximately 400.000 and 650.000 tonnes/ year during the eighties and nineties.

Considering these conditions, it is no wonder that fisheries issues are under constant public debate in Iceland. The resource situation, the economic performance of the industry and last but not least the fairness and effectiveness of the resource management system are not internal issues within closed fisheries circles, they are issues of great concern for the public at large.

Transparency is another important characteristic for Icelandic fisheries. In 1996 there were only 2000 registered vessels ( 800 decked vessels) and 61 fishing ports. The structure of the industry makes it relatively manageable in terms of control, reliability of catch statistics and enforcement costs in general. 
For these and other reasons, Iceland is an interesting case for the study of marine resource management. Due to the transparency of fisheries sector, Iceland can be seen as a suitable laboratory for the testing of theoretical management models as the system of individual transferable quotas (ITQs). The extensive public debates on fisheries issues on the other hand, can provide documentation on conflicting values and ethical dilemmas surfacing in the wake of new management practices.

Different aspects of the Icelandic experience during the first years of ITQ-management have been subjects of research by social scientists during the recent years. Gísli Pálsson and Agnar Helgason have done extensive work to evaluate the redistribution of quotas and the nature of the quota trade, as well as the public discourse and the moral issues of ITQs (Pálsson and Helgason 1996a, 1996b, 1999 Helgason 1995). In earlier papers I have discussed the distributional effects of ITQs, including the issues of quota leasing, contract fishing and quota market prices as well as the effects of ITQs upon fisheries communities (Eythórsson 1996a, 1996b). Some of this research has been an input to the work of the Committee to Review Individual Fishing Quotas in the US (National Research Council 1999), the first comprehensive review available on the effects of quota systems in the fisheries, from a social as well as economic point of view.

In the current paper I want to take a slightly different focus. First, I will look into conflict and consensus in the decision making processes and stakeholder involvement in decision making. Secondly, I will comment upon the recent development of the institutional/legal framework of the ITQ-system. Finally I will ask whether the ITQ-system has consolidated its position in the industry and whether there are signs of conflict resolution and consensus after more than a decade of bitter conflicts.

\section{The roots of the present management system}

While looking for the rationale and justification of the present system, it is reasonable to start with the extension of the EEZ to 50 nautical miles in 1972 and to 200 nautical miles three years later. The rationale behind the "nationalisation" of the fish resources was twofold: 1) An urgent need to protect the resources, as it seemed evident that the North- 
Atlantic Cod could fall victim to the "tragedy of commons" if it was to remain outside the jurisdiction of any state that could introduce an effective resource management regime. It was considered too risky to wait for a new international management regime to become workable. 2) Protection of Iceland's national interests. It was argued that the national economy, and indeed the future of Iceland as an independent state, was totally dependent upon the fish resources. Consequently, national control over these resources was a necessity from economic and political points of view.

The Icelandic policy of taking national control over the resource base in the ocean was met with a fierce opposition from other fishing nations, especially Britain who sent her navy to protect British fishing vessels in Icelandic Waters. In Iceland the decision was based on a very broad consensus among political parties and every stakeholder organisation within the fisheries sector. The foundation of the Icelandic fisheries management policy, the combination of ecological issues and national interests, was understandably enough an issue of a broad consensus and popular mobilisation. It can be argued, that while fisheries management was an issue of great consensus and national unity during the 1970s, it became the most dividing and conflict-laden issue of Icelandic politics and public debates in the nineties.

\section{The introduction of resource management in the fisheries}

As Britain withdrew from the last "Cod War" in 1976, Iceland could finally harvest the resources within its EEZ without foreign competition. In practice, the resources were been appropriated as national property. Ownership over the resources implies however not only the right to harvest it, but an obligation to manage and protect it as well. Soon it became clear that such an obligation would represent a major challenge.

In the early seventies, it seemed reasonable that the departure of foreign vessels from Icelandic waters would allow for a substantial increase in catches by the domestic fleet. During the sixties, approximately one third of the total catch had been taken by foreign vessels. These promising prospects triggered a rush of investment in modern fishing trawlers, and the fleet of stern trawlers increased from nil in 1970 to impressing 80 vessels in 1980. The optimism of the early seventies was however staggered by the so- 
called "black report" from the Marine Research Institute in October 1975. The report concluded that the condition of the cod stock was poor, and it could in a worst case suffer the fate of the North-Atlantic Herring, a stock which collapsed dramatically in 1967-68. As a reaction to the apparent threat to the cod stock, the Government introduced a TAC for cod and a set of restrictive measures in 1976. In essence, these measures were aimed at limiting fishing effort, especially in the cod fisheries. Each vessel was obligated to refrain from cod fishing for a certain number of days each year, and measures were taken to restrict the entrance of new vessels into the fisheries. The Marine Research Institute was also authorised to close fishing grounds on short notice if necessary in order to protect juvenile cod.

With certain variation from one year to another, these measures were in effect from 1977 to 1983 . By 1983, the cod stock was once again in a poor condition. It seemed evident that the current management measures had not been sufficiently effective. The fishing fleet continued to grow and the TAC for cod was repeatedly exceeded. This was the background for the introduction of vessel quotas in the demersal fisheries from 1984. The debate and the political process prior to the decision will be discussed further after the introduction of the stakeholder organisations in the fisheries.

\section{Stakeholder organisations and representations}

In essence, Icelandic fishermen belong to different unions and associations depending upon their employment status. Hired deckhands are organised in the Union of Seamen (Sjómannasamband Íslands; SSÍ), officers (skippers and mates) are represented by the Officer's Union (Farmanna- og fiskimannasamband Íslands; FFSÍ), while engineers have organised themselves in a separate Engineer's Union. Their employers are represented by the Association of Vessel Owners (Landssamband Íslenskra Utvegsmanna; LÍÚ). Since 1985, owners of small boats are organised in a separate association (Landssamband smábátaeigenda; LS). All these organisations have more or less been represented in different task forces and committees appointed by Government for reviewing the fisheries policy during the last three decades. Fish processors and marketing units are also 
organised and have in some cases been represented in government committees. Besides, since a large fraction of the fishing fleet is owned by vertically integrated companies, the

processors are to a certain degree represented by LÍÚ as well. The stakeholders who have probably been least involved in decision making and policy design in the fisheries are the fish workers employed at the processing plants. They were however represented by their Workers Union (Verkamannasamband Íslands; VMSÍ) in two fisheries task forces during the 1980s (Pálmason 1992).

Another important organisation is Iceland's Fisheries Association (Fiskifélag Íslands; FÍ). Founded in 1911, it was originally an ideal organisation for furthering fisheries development in general. Besides being a service organisation and a semi-governmental office for keeping record of fisheries statistics, the Association has for many years constituted a forum for fisheries debates involving the different interests within the fisheries. The Association arranges the annual Fisheries Assembly (Fiskithing), where the different unions and organisations for the harvesting, processing and marketing sectors are represented, along with the representatives from the regional units of the Fisheries Association itself. With its broad functional and regional representation, the Fisheries Assembly is an important forum for debates on fisheries issues and policy. In a number of cases, the national fisheries policy has been strongly influenced by the recommendations supported by the majority of the Assembly representatives.

\section{The introduction of management by vessel quotas}

The decision to introduce vessel quotas in the demersal fisheries was taken in the face of bleak prospects for the cod stock in 1983. During the previous years, there were prolonged debates over the issue within the stakeholder organisations, culminating at the Fisheries Assembly in 1983. While a vessel quota solution was supported by a majority of boat owners and the regional representatives from the Northeast and East, the opposition was concentrated among the representatives of the Officers Union (FFSÍ) and the regional representatives from the Northwest (Westfjords) region. At the Assembly the opposition 
found itself in a minority position and accepted to support a recommendation to the Government to try out a system of vessel quotas for one year. According to the Assembly resolution, the system would be considered as an experiment and was to be reviewed as soon as the cod stock had recovered. On the basis of this consensus, the Icelandic Parliament passed a Fisheries Management Act in December 1983, almost without debate. The new law was very brief, it authorised the Ministry of Fisheries to work out the details of the quota system.

According to rules introduced by the Ministry, the initial allocation of vessel quotas was to be based on the catch history of each vessel for the three previous years. While regulation by catch quotas was introduced as the basis of the new management system, there was also another option; boat owners could chose to fish within a system of "effort quota" based on a limited number of days at sea. The effort quota was originally designed as a safety valve, an opportunity for owners of boats who had for some reasons been idle during the previous years. But from 1985 on it became an attractive alternative for all those who felt discontent with their share of the TAC. Small boats, up to 10 gross register tonnes (GRT) were not included in any of the systems, but were initially allowed to fish practically without restrictions. From 1985 on their catch was regulated by a sort of effort-quota, designed specially for this group.

In order to solve adjustment problems and resolve disputes about unintended or unfair outcomes of the quota allocation, the Ministry of Fisheries appointed the leader of the boat owners in LİÚ and a representative of the employed fishermen (alternating between thel leadership of FFSI and SSI) to a Consultative Committee (Samrádsnefnd). The third member was from the Ministry of Fisheries. As it turned out, the Committee became extremely busy, especially during the first half of 1984. From late January to the end of May it had no less than 65 meetings. The Committee had to handle a great number of complains from boat owners and took on the responsibility of correcting and in some cases redistributing quota between vessel groups and individual vessels. By handing these problems over to the representatives of the major stakeholders in the harvesting sector, the Government managed to maintain an atmosphere of consensus within the industry. 
The committee remained very active until 1990, but was discontinued in the first half of 1991, after the introduction of the new Fisheries Management Act.

With some minor changes, the quota system was prolonged until 1990. Quotas were transferable to a certain degree, but could only be transferred from one vessel to another if the first vessel was permanently removed from the fisheries. Exchange and leasing of catch quota within a year was allowed, and could freely take place within the same fishing community or between vessels owned by the same company. Transfers involving vessels form different communities had to be applied for to the Ministry in each separate case and were also subject to consultations with the involved municipalities and workers unions.

The quota system was changed several times during the period from 1984 to 1990, but in essence it worked only in a limited sense as a system of individual transferable quotas (ITQs). The regulations were relatively complex and a number of loopholes allowed for increased catches. Especially in 1986-87 it could seem that the quota system would "wither away", as a majority of boat owners had opted for the effort-quota alternative in order to increase their share of the TAC at the expense of those regulated by ITQs. At the same time small boats, who were subject to a more liberal regime, became extremely popular. While 964 small boats were registered in 1984, their number had increased to 1.956 in 1990 (Pálmason 1992). As small boats became more numerous and more effective, their aggregate cod catches increased from 16.572 tonnes in 1984 to 47.724 tonnes in 1990, a relative increase from $4 \%$ to $14 \%$ of the total cod catches (Ibid). Pálmason (1992) has studied the decision- making processes prior to changes in the system from 1984-91, including stakeholder representation in five different preparatory committees appointed by the Government during this period. He finds that the committees who prepared the law revisions in 1984 and 1985 were small (7 persons), with representatives mainly from the fisheries administration and the harvesting sector. But by the end of the period (law revisions of 1988 and 1990) there was a tendency towards larger committees (up to 24 persons) with a broader range of representatives. He 
explains this development in terms of growing consciousness among interest groups outside the harvesting sector, as well as within the political parties. The importance of participation in the decision making process became more obvious for different interest groups as it became widely realised that fisheries management was no longer a question of temporary technical measures to protect fish stocks. Gradually it became clear that the allocation of fishing rights was likely to become permanent, and that it was going to influence the future development of regions and communities as well as the economic viability of different vessel groups within the fisheries.

The consensus-based policies of the 1980s can be seen as result of the broad alliance between stakeholders in the fisheries, created during the Cod-Wars in the seventies, and the small community-like Icelandic society which could ill afford deep internal conflicts within its basic industry. Basing their statement on Gísli Pálsson’s work, McCay and Acheson (1987:33) characterised Icelandic fisheries management during this period as comanagement:

"The Icelandic management process is open and flexible, able to respond to and incorporate the interests of diverse actors and groups, in sharp contrast to the systems portrayed by Anderson and Pinkerton ${ }^{l}$ and those with which we are familiar in the United States.

Comanagement is a social reality in Iceland; it does not need a special label, nor need it be based on either homogeneity on the part of the users or total accord between users and managers. Accordingly, the state is trusted in Iceland. The boat quota system being considered in the 1980s will privatise rights to catch fish in a property mimicking way. It is controversial because of realistic worries about its effects on the structure of the industry But if it is accepted it will be partly because the state is trusted to be impartial in the assignment of quotas, a trust that enables the continuation of the ideology of equal, or equitable, access and the effective management of a limited good."

The quotation describes quite well the situation in the mid-eighties; the state could still build upon the trust established by the broad national consensus during the seventies. The stakeholder organisations could also participate in the management discourse with more or less equal voices. The dividing line between quota owners and the others was not yet well defined.

\footnotetext{
${ }^{1}$ Anderson, E. N. Jr. : A Malaysian Tragedy of the Commons, and Pinkerton E. : Intercepting the State: Dramatic Processes in the Assertion of Local Comanagement Rights. Both in McCay and Acheson (1987): The Question of The Commons The Culture and Ecology of Communal Resources. The University of Arizona Press, Tucson.
} 


\section{Permanent allocation and transferability: The 1990 Fisheries Management Act}

During 1988- 1989 the development seemed to indicate that the management system was not working according to its goals. There were signs of economic crisis in the industry, and the loopholes in the system made it extremely difficult to enforce the established TAC for cod. Despite the restrictive policies of the Government, the investments in the fishing fleet and consequently the total catch capacity continued to increase. The industry also complained that the system was too complex. In addition, the industry found longterm planning difficult as the management system was subject to unforeseeable modifications on almost annual basis.

The 1990 Fisheries Management Act, which established an ITQ-system in Iceland's fisheries management came about after prolonged controversies in the Fisheries Assembly as well as in Parliament. Compared to the debate in 1983, it had become more difficult to reach consensus in the FA, but the opponents of quota management were still a minority among the representatives. Meanwhile, the political controversies, both within parties and between parties in Parliament had grown stronger. Fears were expressed that permanent allocation of quota shares to boat owners would mean a de-facto privatisation of the resources and an increased insecurity for fisheries-dependent communities.

By the late eighties, the debate had become increasingly influenced by fisheries economics, especially the theoretical model of resource management by ITQs. The focus of interest was moved from resource protection to the question of economic efficiency in the fisheries. It was argued that while permanent allocation of quotas would provide conditions for long term planning and sound investment behaviour, free transferability would provide flexibility and efficient use of capital. Inefficient vessels would be bought out, while efficient ones would be able to optimise their operations. Some economists also argued that the efficiency generated by ITQs could produce a basis for management by resource rentals. Resource rentals (annual payments from quota holders to the state in return for the privilege of harvesting the fish resources) could subsequently become an 
important source of revenue for society at large. The ITQ-system was partly justified by practical reasoning on behalf of the LÍÚ, such as the need for predictability and flexibility, and partly by theoretical reasoning by fisheries economists focused on efficiency and the potential benefits of the resource rent upon the national economy.

By the 1990 Fisheries Management Act, TAC-shares were allocated permanently to the boat owners, by prolongation of previous allocations. According to $\S 1$ in the law, the fish resources would remain national property, as the rights allocated to quota holders could not be considered as private property in constitutional sense. The effort quota option was abolished, the only exception was small boats, up to 6 BRT, who were still to be subjects to an effort-quota regime.

Another important change was a broad liberalisation of quota transfers. TAC-shares became divisible and could in effect be transferred as a separate commodity, not only a part of the market value of a fishing vessel. Quota transfers could however only take place between owners of Icelandic fishing vessels. Exchange and leasing of annual quota for any particular species was also liberalised and could in practice take place without consulting the Ministry of Fisheries or the involved communities and unions.

In a sense, the 1990 Fisheries Management Act turned Iceland into a test site for a market-based fisheries management system. It provided a basis for a quota "stock market" which continuously redistributes fishing rights between vessel owners, communities and regions. Some of the effects of the system had been predicted by economists and policy makers, but ITQs also produced some unexpected side-effects.

\section{Concentration of quotas and changing fleet structure}

A quick review of the first decade of ITQs in Iceland, will indicate that the system has in fact improved the economic efficiency of the fisheries as predicted by the proponents of the system. On the other hand, the worries expressed by the sceptics, about increased vulnerability of fishing communities as a result of ITQs have also proven justified. 
A principal prediction of the theoretical model is that ITQs will cause a withdrawal of catch capacity from the fisheries. By counting the number of fishing vessels, one is bound to reach the conclusion that the fishing fleet has severely decreased since the introduction of quotas. However, by comparing figures on gross register tonnes and engine capacity, one will find that in these terms, fleet capacity has been gradually increasing despite the ITQ-system (table 1). Since the introduction of ITQs in 1984 to the end of 1997, the fleet has in these terms expanded by almost 13\%, or 14.100 GRT. Engine power, which also provides an indication of catching capacity, has increased correspondingly.

Table 1. The Icelandic Fishing Fleet 1984-97 ('000 GRT)

\begin{tabular}{lrrrrc} 
Vessel type & $\mathbf{1 9 8 4}$ & $\mathbf{1 9 8 9}$ & $\mathbf{1 9 9 5}$ & $\mathbf{1 9 9 7}$ & Change 1984-97 \\
Trawlers >500 grt & 16.0 & 24.1 & 39.7 & 43.5 & 27.5 \\
Trawlers <500 grt & 35.1 & 32.1 & 25.6 & 24.6 & -10.5 \\
Other > 200 grt & 28.0 & 32.5 & 30.5 & 32.7 & 4.7 \\
Inshore 12-200 tns. & 29.6 & 28.8 & 22.8 & 21.7 & -7.9 \\
Small boats <12 grt & 2.1 & 3.3 & 2.6 & 2.4 & 0.3 \\
Total & 110.8 & 120.7 & 121.2 & 124.9 & +14.1 \\
\hline
\end{tabular}

(Source: Útvegur 1984 - 1997)

Disaggregation of the data creates a more complicated impression. For the inshore fleet, defined as vessels from 12 to 200 GRT, there is a great reduction, by tonnage -7.900 GRT $(27 \%)$.

The trawler category has increased by 17.000 GRTs. The increase can be explained by the growth in the factory trawler fleet. These trawlers have space consuming processing facilities on board, and the relation between tonnage and fishing capacity may not be comparable to other vessels. However, considering the technological development in the fisheries, it is reasonable to believe that the fishing capacity of an average 1000 GRT trawler in 1997 is somewhat improved compared to a similar vessel in 1984. 
Small coastal vessels, below 12 GRT increased in the late eighties, but are now back to the 1984 level. The growth of the factory trawler fleet may be partly explained by the options they have to fish outside the EEZ, and by the bargain prices on used vessels following the collapse of the cod fisheries in Canada.

As a response to the continued increase in catch capacity, the Icelandic government initiated a buy back programme in 1994, aimed at removing vessels from the fisheries. By June 1995, the Fisheries Development Fund had bought out 172 vessels (5.738 GRT), mainly from the small and inshore sectors. The buy back programme in itself indicates that the government's expectations of the ITQ system as a measure for capacity reduction had not been fulfilled. This buy-back program was special since its primary aim was not to buy excess quota. The objective was twofold; 1) to remove small vessels from the effort-quota regime in order to minimise the effort-quota group, and 2) to remove vessels with little or no quota, in order to reduce the demand for quota on lease and lighten the pressure on leasing prices.

There has been a substantial concentration of quota shares within the larger, vertically integrated companies since the introduction of ITQs, and especially since 1991. Pálsson and Helgason (1996a, 1999) have demonstrated that "giants" (22 companies each holding more than $1 \%$ of total ITQs) held $47.2 \%$ of total ITQs in 1994 , compared to $25.5 \%$ in 1991. Recent figures indicate that the concentration is continuing. In 1998/99 the five biggest quota owners held $25 \%$ of the total TAC, and the 20 biggest held $56,6 \%$ (Kvótabókin 1999). Responding to the growing concentration of quota ownership, an upper limit to TAC shares that can be held by a single owner was set by the Parliament in March 1998. One owner can hold up to $10 \%$ of TAC-shares for cod and haddock and $20 \%$ of TAC-shares for other demersal species, herring, capelin and shrimp. The enforcement of such limits may however prove complicated, in the light of the ongoing concentration of ownership structure within the industry (Garðarsson 1999).

The concentration process has accelerated by the end of the nineties, especially by more concentrated ownership structure and mergers within the industry (Viðskiptablaðið 8.-14. 
September 1999). Along with a general liberalisation of the economic policy in Iceland, there is a trend towards an ideological shift within the industry, leaving behind the idea that fisheries and fish processing should be locally embedded in fisheries communities. Many fisheries companies have joined the Icelandic stock-market, and ownership is in many cases not linked to any particular community. Investors without fisheries background are now well represented among the owners of quota holding companies (Garðarsson 1999).

Direct transfers of quota shares have become less common in the late nineties ${ }^{2}$, while small quota owners are likely to merge with bigger companies and receive company shares in exchange for their quota shares ${ }^{3}$. The reduction in regular quota transactions may be explained by several factors. One, but not very likely hypotheses is that quota distribution is now well adapted to the fleet structure and that quota transfers are no longer required. Another reason might be that more effective taxation of quota holdings along with restrictions on quota leasing (see below) have made regular quota transactions less attractive.

\section{Resolution of conflicts over contract fishing}

During the early nineties, new types of relations emerged in the fisheries as a consequence of quota leasing and contract fishing (Eythorsson 1996a). Contract fishing is often referred to as "fishing for others", which means that a vessel owner short of quota enters a leasing contract with a quota owner. Fishing contracts were in many cases signed between inshore vessels with small quota holdings and companies with large quota holdings. The vessels were then obliged to deliver their catches to the company in return for a fixed price (market price for raw fish minus the quota leasing price). In 1993 the average fixed price for raw cod in contract fishing was about half the market price, the remaining half representing the payment for quota leasing (Eythórsson 1996a). This practice influenced the income of crew members in a negative direction, as they receive a

${ }^{2}$ Interview with B. Jónsson, LiÚ, September 1999. 
fixed share of the fish price on delivery. While contract fishing became more widespread, more crewmen experienced a drop in their income. According to the crewmens' unions, speculative leasing transactions (kvótabrask) were in some cases undertaken in order to reduce wages. This was the background of the crewmens' strike in January 1994 and repeated strikes in 1995 and 1998. After many rounds of negotiation, new institutional framework was set up in March 1998, to control prices, resolve disputes and to control leasing transactions. A new Share-price Office (Verðlagsstofa skiptaverðs) is established in order to control landing prices and thereby secure a fair renumeration of crew. A standing committe with representatives from organisations from both sides (Úrskurðarnefnd sjómanna og útvegsmanna) has been set up to resolve price disputes between boat owners and crew. The committee is linked to the Share-price Office. Finally, a stock-market like structure has been set up to control leasing transactions; the Quota Exchange Market (Kvótaping). In essence, all quota leasing transactions, apart from exchange of species and transactions between vessels held by the same owner, must now take place anonymously at the $\mathrm{QEM}^{4}$, which means that in effect contract fishing in the form described above is no longer allowed.

According to the organisations of crewmen ${ }^{5}$ these institutional reforms seem to have somewhat eased the situation of crew members, as leasing transactions have become less common. The secretary of SSÍ has however concluded that the problem is not solved after the first year of experience (Jónsson 1999). Market prices at the QEM are extremely high, especially for cod quota, a situation which indicates that quota leasing is now only viable as a solution to adjustment problems of matching the composition of species in the catch to the quota holdings of a vessel.

The conflict between vessel owners and crewmen over contract fishing has dominated the ITQ-debate in Iceland for many years, and to a certain degree overshadowed other critical questions such as the vulnerability of fishing communities.

\footnotetext{
${ }^{3}$ Interview with B. Bragsaon, Byggdastofnun, September 1999.

${ }^{4}$ Transactions are mediated by the QEM, buyers and sellers are not supposed to know about each other.

${ }^{5}$ Interviews with H. Jónsson secretary of SSI and B. Valsson secretary of FFSI in September 1999.
} 


\section{Dependent communities}

Recently, the situation of fishing communities as a result of the ITQ-system has come into the foreground of the debate. Some communities have become marginalised as a result of a loss of quotas. The geographical and economic structure of Icelandic fisheries, with many remote villages, traditionally organised as single-enterprise communities has been described by Eythórsson (1996b) and Skaptadóttir (1996). During the nineties, the vulnerability of fishing communities, especially small communities with poor employment alternatives, has become more visible as several fishing villages have lost most their quota as the owners have moved or sold out. A comparison of different size categories of fishing communities, gives a clear impression that small communities, with less than 500 inhabitants have on the average lost a much larger share of their quotas than the bigger communities (Eythorsson 1996b, Garðarsson 1999).

Until 1998, contract fishing was a possible option for fishermen in some of these communites, but measures taken to limit contract fishing have in practice removed that (not so attractive) option. The loss of flexibility allowed by contract fishing, has thus generated negative implications for communities short of quota. Communities without quota are left without many options for coping with the situation. Contract fishing is no longer an option, and the alternative strategy for re-entering the fisheries by "small boats" who have been able to operate outside the ITQ-system, has become almost impossible. Communities in trouble are asking for solidarity from the government, but any intervention involving. redistribution of quotas is difficult in a system where quotas have in practice acquired a status of private property.

\section{Legal questions}

The somewhat confusing legal status of quota as "semi-privatised" has evoked complicated debates over the issues of taxation, depreciation and the use of quota shares as collateral for loans. In which sense is it possible to buy and sell something which is legally defined as public property? And would such a thing be liable to taxation? Should banks accept public (or national) property as collateral for private loans? 
Before 1991, the value of quota shares was treated as a part of the value of a vessel, since vessels and quota shares could not be separated. In consequence, quotas could be depreciated by the same rate as the vessels, and were treated as collateral for loans in the sense that they contributed to the market value of a fishing vessel. After 1991 the situation became somewhat unclear. In some cases investment in quota shares was considered as an expenditure, and quota holdings were not treated as real capital, which meant that they could not be used as collateral. But in 1993 the Icelandic Supreme Court found that quota holdings should be taxed as private capital ${ }^{6}$, while they could be depreciated by the same rate as copyrights, -20 per cent annually.

At first, the collateral problem was solved by mutual agreements between banks and boat owners to ensure that quota shares and vessels could not be separated without consulting the bank, but as the legal status of these agreements was not considered satisfactory, the use of quotas as collateral was eventually liberalised.

The generous depreciation rate for quota shares has also been removed.

In the long run, it has proved difficult to uphold the paradoxical status of quota shares as public property according to the law, but private property for all practical purposes. This was illustrated by a Supreme Court verdict in December 1998. The case was raised by a fisherman who had been denied a fishing licence and a catch quota. The denial was based on the fact that the fisherman in question had not been an owner of a fishing vessel during the early eighties, when fishing experience became converted into fishing rights. Considering the Icelandic constitution, which claims equal employment rights for every citizen, and the Fisheries Management Act of 1990, which defines the fish resources as public property, the majority of the Court found the denial unlawful an d unconstitutional. In short, the Court found that by introducing the ITQ system the government had given away exclusive rights to the publicly owned Icelandic fish resources. These rights had been given away permanently to a group of people who happened to be the owners of active fishing vessels at a certain point of time. Such an act could not be justified by the need to preserve the resources or by the best public interests. The ITQ system as such was

\footnotetext{
${ }^{6} \mathrm{An}$ interesting aspect of the taxation question is that while quota shares which have been bought and paid for are liable to taxation (and
} 
not considered unconstitutional, the constitutional problem was linked to the permanence of the allocation. A year later, another quota case ${ }^{7}$ passed Low Court, in a case where a vessel had delivered catches without possessing corresponding quota rights. Somewhat surprisingly, the vessel owner won the case, but in April 2000 the verdict was overridden by the Supreme Court. This time the majority of the Court found that the permanent allocation of quotas was not against the Constitution, as quota holdings are not formally defined as private property. In both cases, the minority of the Court voted differently.

These cases demonstrate that the ITQ legislation has not been sufficiently well designed from the start and that it did not anticipate the wide ranging consequences of permanent quota allocation. With a more cautious approach, such as by a temporary allocation of quotas for 5-10 years, the Government might have avoided the problematic legal situation created by permanent allocation. With permanent allocation, a "point of no return" has been passed. Even if the allocated rights could in principle be taken back without compensation, the economic implications for those who have invested in permanent TAC shares would be serious.

\section{Consolidation without consensus?}

During the 1990s, the Icelandic fisheries have been transformed from being a strictly regulated, corporatively organised industry with units of production embedded within local communities, to a globally oriented free market industry with highly mobile units of production. This process is certainly not generated by the ITQ system alone; a wide range of liberalisation policies have, in sum, created a free market environment in the fisheries. The transformation of fishing rights into capital, represented by quota value, has been an important contribution to the present economic strength of companies with large quota holdings. In terms of export value of fish products and profits made by leading fisheries companies, there is little doubt that the ITQ-management has been a success. Icelandic

\footnotetext{
depreciation) while quota shares which were allocated gratis in 1984 and have not yet changed hands, are not liable to taxation. "The case is referred to as "Vatneyrarmálio" arose as the vessel Vatneyri BA, which dliverd excess catch on purpose in order to try the issue of quota allocation in court.
} 
fishing companies are expanding into international waters and demonstrating their competitiveness in terms of technology and know-how. The system has consolidated its position through a series of court cases that have reinforced the status of quota shares as de facto private property.

Despite this apparent success, there is still no consensus about the ITQ system in Iceland. After almost a decade of experience, the controversies within the industry and in Icelandic politics seem as strong as ever. Repeated polls among the population have shown that a majority of the public is either sceptical or opposed to the system, and a new, anti-ITQ political party got two MPs in the last elections.

The critic against the system is in essence aimed at its distributional effects. The initial allocation of ITQs led to a gratis distribution of valuable rights to certain families, and in some cases these families have enjoyed great windfall gains from selling out their shares. As the Supreme Court decision in 1998 called the legality of this procedure into question, this critic was reinforced. The distribution of economic, political and negotiating power within the fisheries as well as in society at large is also influenced by the system. As quota owners, the vessel owners association (LÍU) is in a superior position compared to the crewmen's unions and other stakeholders' organisations. The practice of working out the fisheries management policy by broad debates and consensus in the Fisheries Assembly and by preparing new legislation by task forces with broad representation from different stakeholder groups is now more or less abandoned. At present, two task forces are working on the question of reforming the quota system; the resource committee "Auðlindanefnd" and a committee for reviewing the fisheries legislation, also referred to as the "consensus committee" as its objective is to resolve the controversies of the fisheries management system and try to make peace. None of these committees has stakeholder representatives, the members are politicians, lawyers and economists. One of the reasons is probably that the differences between principal stakeholder groups have grown deep, and that after a decade of bitter conflicts, some of them are hardly on speaking terms. 
Fisheries dependent municipalities and coastal communities are strongly dependent upon quota owners for their survival and no one seems responsible for the victims of the system; the people living in communities which the quota owners have abandoned. There is a bitterness among people who have realised that their lifetime savings in houses of residence in formerly prosperous fishing communities is now worth next to nothing in terms of market prices.

It is however legitimate to ask how the ITQ-system has been able to survive and consolidate its position despite the lack of consensus and apparently against the will of the majority of the public. One reason may be that the crucial decisions taken at the early stages of the system from 1984-1991, have proved to become increasingly difficult to reverse as time passes. Another complicating factor is that all major political parties and many stakeholder organisations have at one point or another been involved in the design of the system and have to a certain degree been co-opted during the decision making process. The opposition to the ITQ-system is not homogenous, and there is little agreement about what the alternative should be. In a recent poll published in Agir, the journal of the Icelandic Fisheries Association (1999), only 7,1\% of the respondents wanted to keep the present system unchanged. However, only 17,3\% wanted to abolish the quota system altogether. One third $(33,3 \%)$ of the respondents favoured some kind of regional allocation or "community quota". Almost one-third (29,2\%) was favourable to either resource rentals or quota-auction, while $10,5 \%$ wanted a special tax on quota transactions.

Despite the critical attitude towards the system, the basic principle of fisheries management by some sort of transferable quotas now seems widely accepted among the Icelandic public. According to the poll quoted above, a consensus solution should take into account the insecure situation of fishing communities, it should safeguard the income of fishing crew, and include payments of resource rentals, taxes or cost recovery from those who have benefited from the system. 


\section{References}

Anonymous (1984-1993), Útvegur, a Yearbook of Fisheries Statistics, published by Fiskifelag Islands, Reykjavik.

Eythórsson, Einar 1996a: Theory and practice of ITQs in Iceland; Privatization of common fishing rights. Marine Policy Vol 20 No 3 pp 269-281

Eythórsson, Einar 1996b: Coastal Communities and ITQ Management. The Case of Icelandic Fisheries. Sociological Ruralis Vol. 36 No 2 pp212- 223.

Garðarsson, Halldór Jón 1999: Kvótakerfið . Áhrif pess á próun lýðraðis. BA-thesis in political science, Univesity of Iceland.

Helgason, Agnar. (1995), The Lords of the Sea and the Morality of Exchange: The Social Context of ITQ Management in the Icelandic Fisheries, unpublished M.A. thesis in Anthropology, Faculty of Social Science, University of Iceland

Jónsson, Hólmgeir (1999): Pað stefnir í átök enn á ný. Fiskifréttir, 5. mars 1999.

Kvótabókin (A yearbook of quota statistics) Fróði h.f. Reykjavík.

McCay , Bonnie and James M. Acheson (1987): The Question of the Commons. The Culture and Ecology of Common Resources. The University of Arizona Press, Tucson.

National Research Council, Committee to Review Individual Fishing Quotas (1999). Sharing the Fish. Toward a National Policy on Individual Fishing Quotas. National Academy Press, Washington D.C.

Pálmason, Snorri Rúnar 1992: Allmenn tragedie på Island? Thesis for the fisheries candidate degree, The Norwegian Fisheries College, Troms $\varnothing$.

Pálsson, Gísli and Agnar Helgason (1996a): Figuring Fish and Measuring Men: The Individual Transferable Quota System in the Icelandic Cod Fishery. Ocean and Coastal Management Vol. 28(1-3) pp 117146.

Pálsson, Gísli and Agnar Helgason (1996b): Property Rights and Practical Knowledge: The Icelandic Quota System. In Crean, Kevin and David Symes (ed): Fisheries Management in Crisis. Fishing News Books/Blackwell Science, Oxford.

Pálsson, Gísli and Agnar Helgason (1999): Kvótakerfið, kenning og veruleiki. Skírnir 1999 (Reykjavík)

Runólfsson, Birgir 1997: The Icelandic Fishing Industry: A Discriptive Account. A paper for the Symposium on the Efficiency of North Atlantic Fisheries. Reykjavík, 12.-13. Sept. 1997.

Skaptadóttir, Unnur Dís (1996): Gender Construction and Diversity in Icelandic Fishing Communities. Anthropologica XXXVIII (1996) 271-287

Útvegur (A yearbook of fisheries statistics, puplished by the Icelandic Fisheries Association) 1984-1997. Reykjavik. 
Viðskiptablaðið (a business weekly), Reykjavík. 